\title{
The Environmental Impact of Pipeline Vandalism - A Challenge to Biodiversity in Portharcourt Area of Rivers State, Nigeria
}

\author{
Sanusi Aishatu ,Onovo Josiah Chukwudi and Isa Hauwa’u
}

\begin{abstract}
A study was undertaken between March and November, 2015 in Portharcourt area of Rivers State, Nigeria to determine the effects of pipeline vandalism on the biodiversity in the region. The presence of potential energy from oil, made Portharcourt to become one of Nigeria's most important industrial cities. The environmental problems as a result of oil spillage mostly caused by pipeline vandalism in Portharcourt area include freshwater pollution, air pollution, chemical pollution, soil and land pollution, unsustainable agricultural practice such as fish farming, biodiversity depletion, habitat and ecological systems loss and insecurity. Data were collected through the use of applicable sampling techniques. Results revealed that constant oil spills from these pipelines constituted health hazards for both the people and the environment. Involvement of the host communities in the processes that guarantee the safety of oil installations and best practice for prudent pipeline management in Portharcourt, River State and the country at large are hereby recommended.
\end{abstract}

Keywords--- Biodiversity, oil spills, pipeline vandalism, Portharcourt

\section{INTRODUCTION}

Portharcourt is the capital of Rivers State in Nigeria. It lies along the Bonny River and has a population of 1,382,592 people according to the 2006 National Population Census. The city was named after Lewis Vernon Harcourt, then the Secretary of State for British Colonies in 1913 by the then Governor of Nigeria, Sir Frederick Lugard. The colonial administration of Nigeria created the port to export coal from the collieries of Enugu located about 243 kilometres north of Portharcourt, to which it was linked by a rail [1].

Prior to the colonial era, the area used to be the farmlands of the Diobu village group of the Ikwerre, an Igbo sub-group [2]. In 1956 crude oil was discovered in commercial quantities at Oloibiri, and Port Harcourt's economy turned to petroleum when the first shipment of Nigerian crude oil was exported through the city in 1958. With the development of the Nigerian petroleum industry, Portharcourt is now the petroleum nerve center of the vast deposits of crude oil being produced from the Niger Delta region and also has a major refinery referred to as the "Portharcourt Refinery" [2].

Department of Biological Sciences, Nasarawa State University, Keffi,, Nigeria. *Corresponding e-mail: onovojos@yahoo.com, Phone no. $+2348065709649$
The area is crisscrossed by thousands of kilometers of pipelines emanating from crude oil production centers to crude oil export facilities or the Portharcourt Refinery. The pipelines are often located close to farmlands and in some cases even crossing water bodies that serve as source of water to some rural communities. One fundamental problem that faces Portharcourt today is the degradation of its ecological environment and biodiversity by oil spillages arising from pipeline vandalism. According to [3], the area has been intensely polluted with tragic consequences for the economy of the people and the totality of the quality of life. A significant feature of the socio economic life of the Portharcourt people is environmental degradation and is largely the outcome of pollution from the exploitation and transportation of crude oil through pipelines.

In recent years, Nigeria lost more than 6 billion dollars of its total oil production to oil spills emanating from vandalized crude oil pipelines and oil theft. Though the prevalence of militancy in the Niger Delta and Portharcourt in the mid2000s accounted for a significant amount of the crude oil spills, the environmental consequences will linger for a long time. While militancy has significantly attenuated in the aftermath of the Amnesty deal in 2009 [4], pipeline vandalism for the purpose of crude oil theft appears to have risen both in incidence and impact.

Pipeline is one of the effective means of uninterrupted and steady supply of crude oil [Figs. 1 and 2]. This medium ensures that consumers get their product at the right time. This mode of transportation has existed for over a century, and helps to reduce accident, spillage, and environmental pollution.

Vandalism is an action involving deliberate destruction of public or private property. Within the civic domain, vandalism denotes willful destruction of public or government property in keeping with criminal or political intent. Oil pipeline vandalism therefore implies deliberate breaking of oil pipelines with the intent to steal petroleum products or to sabotage the government [5]. In Nigeria, oil pipeline vandalism has been perpetrated principally by criminal syndicates who are motivated by the desire to loot oil products for material gains. Oil pipeline vandalism is also known in Nigeria as oil bunkering, which is the act of drilling into the pipelines with the intent to steal products. This situation has been made worse by the prevailing socioeconomic crisis in the nation. 
According to [6], the activities of pipeline vandals resulted in a colossal cost of over $\$ 174.57$ billion in product losses and repairs of pipelines within the last 10 years. The environmental consequences of these include widespread ecosystem damage, loss of biodiversity and socioeconomic problems. Indeed, the incidence of oil pipeline vandalism has been on the rise in Nigeria. According to the 2013 annual report of the Nigerian Extractive Industry Transparency Initiative [NEITI], Nigeria lost a total of 10.9 billion US Dollars to oil theft between 2009 and 2011 [7]. This loss adumbrates the significance of vandalism as a veritable problem in the Nigerian oil industry. The implication of oil pipeline vandalism vis-a-vis Nigeria's security has been vividly demonstrated by its nexus with economic, environmental, and humanitarian losses and consequences [8]. In effect, oil pipeline vandalism has been associated with consequences which hold negative implications for the environment.

\section{MATERIALS AND METHODS}

A study was carried out between March and November, 2015 in Portharcourt area of Rivers State, Nigeria to determine the effects of pipeline vandalism on the biodiversity in the region that includes the fauna and flora. The method of data collection was through the use of applicable sampling techniques. Since the study population was made up of residents in the study area, a stratified sampling method was used to delimit the area of study into settlements. There were nine settlements, which were then delimited using simple random sampling technique to select respondents for the research work. From these settlements, the study sample was taken.

Information on the population in the settlements of the study area was obtained from the National Population Commission [NPC] Rivers State Office, Portharcourt.

Some of the environmental impacts of vandalism [Figs. 6 and 7] include environmental pollution, threat to life of both fauna and flora, scarcity due to cut off of supply, destruction of large areas of arable land by fire outbreaks and oil spillage [Figs. 3, 4 and 5]. Also, marine and other aquatic organisms, which are important components of human diet are usually killed. When spilled product gets washed into the swamps, streams and rivers, aquatic organisms absorb some of the chemicals into their tissues, thus, could create health problems. The present study analyses the environmental impact of pipeline vandalism in the Portharcourt area of the Niger delta region.

Samples were taken in the settlements that made up Bonny Island. The samples comprised of 100 household heads, which were chosen for convenience due to the limited time available to carry out the research. Well-structured questionnaires were administered to the selected respondents. Sets of questionnaires were administered to the residents including the oil companies for the purpose of determining the existing environmental management, policies, measures as well as the general problems encountered.

Some of the questionnaires were administered to the staff of Rivers State Environmental Protection Agency, who were saddled with the responsibility of environmental protection and management, to get the views of respondents on environmental planning and management problems in the study area. Data for this study were collected from the host communities as well as from the oil companies' officials and used to determine the level of pipeline vandalism and its environmental impacts in the study area. The data collected were analyzed using simple percentage statistical tools.

\section{RESUlTS AND DISCUSSION}

Table I presents the socio-economic characteristics of individuals within the host communities of pipeline vandalism in Portharcourt, Rivers State. Table II presents the achievement and non -achievement of the oil companies toward their host communities on pipeline vandalism. About two-thirds [65\%] of the respondents strongly agreed with the harmful effect of pipeline vandalism on biodiversity in the study area, while $33 \%$ agreed. With respect number of lives lost, $65 \%$ strongly agreed, while $35 \%$ also agreed that so many lives were lost as a result of pipeline vandalism. The high rate of pipeline vandalism implies a vast effect on both flora and fauna in the area.

As regards the issue of damages to Biodiversity, $55 \%$ of the respondents strongly agreed while $42 \%$ agreed to the fact that pipeline vandalism cause a lot of havoc to the Biodiversity in Rivers State. This is in agreement with the findings of [9]. While only $3 \%$ of the respondents seems to have a contrary view of the damages caused to the Biodiversity in the region. Therefore, as regards the damages caused to the flora and fauna, about $100 \%$ of the respondents seems to agree and strongly agreed to that fact of serous damages to plant and animals especially the ones that dwell in the marine environment.

$40 \%$ of the respondents strongly agreed that the oil companies contributed to curbing and controlling the environmental degradation faced by the host communities, $35 \%$ seems to agree while $25 \%$ of the respondents disagreed and strongly disagreed to that fact, respectively. In terms of social amenities provided to the host communities, $10 \%$ of the respondents strongly agreed, $15 \%$ agreed while $75 \%$ seems to disagree and strongly disagreed. This implies that the oil companies did not really provide substantial social amenities to their host communities of oil pipeline vandalism.

With respect to educational facilities assistance, $20 \%$ strongly agreed, $30 \%$ agreed while $60 \%$ both disagreed and strongly disagreed to that fact. As regards the damages caused to the Agricultural farmlands and fish farming activities, $95 \%$ of the respondents seems to strongly agreed and agreed to that fact which agrees with the work of [10] who reported that a great damage had been done to the Agricultural farmlands in the regions of Pipeline vandalism. In terms of health care assistance to the host communities, about $75 \%$ strongly agreed and agreed to that fact while $25 \%$ disagreed and strongly agreed to that fact. In-terms of consultations by the oil companies to the host communities for any project, $55 \%$ have strongly disagreed and disagreed while $45 \%$ strongly agreed and agreed to that fact.

Based on the comments of the respondents, the negative impacts of the pipeline vandalism on biodiversity and the 
health of the host communities have been very pronounced. This implies that drastic measures need to be put in place by the Federal government to curb the terrible situation of pipeline vandalism that pose a serious threat to both humans and the environment at large.

\section{CONCLUSION}

The negative impacts of vandalism of pipelines are enormous. It results in fire disasters, which destroy cash crops such as cocoa, coffee, palm trees, rubber among others, which could have been harvested and sold for income. The vandalism of crude pipelines has continued to take a toll on Nigeria oil production. Most pipelines from the flow station are obsolete. Oil pipes ought to be replaced every 15 to 20 years but most pipelines in use are more than 20 to 25 years old, making them subject to corrosion and leakage. Some of these pipes are laid above ground level without adequate surveillance, exposing them to wear and tear and other damages.

Over the years, vandals of oil pipelines and Nigerian's crude oil thieves have been in business uninterrupted. These criminal activities have left an indelible mark on the country's dwindling economy. This is because oil and gas remain the main sources of national revenue and foreign earnings for over 50 years since oil was discovered. Severally, government had declared total war on these economic saboteurs, but they kept improving on their activities. The more the government, with the aid of security agencies devised means of protecting the oil facilities particularly in the Niger Delta, the more the hoodlums improve on their operations to beat even the modern technologies used in fortifying the oil pipelines and installations.

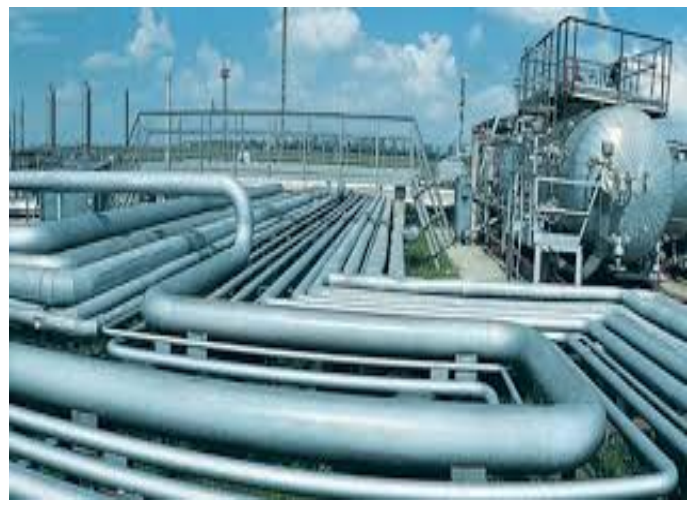

Fig. 1 Pipeline layout at Okrika, Portharcourt

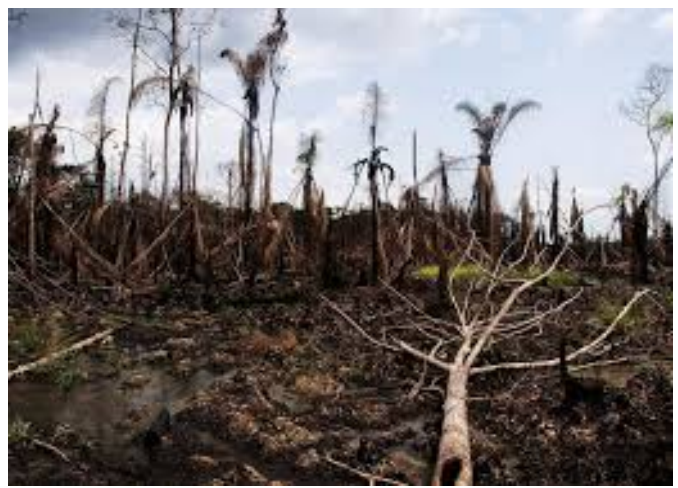

Fig. 3 Impacted vegetation at Ogoni land in Rivers State
Except pipeline vandalism and oil theft are brought to a halt, the Nigerian economy will continue to suffer the loss of revenue from several barrels of oil every day. However, more importantly and too often overlooked, Nigerians will continue to reap the consequences of degraded environment.

\section{RECOMMENDATIONS}

The Federal Government should adopt 'The Principles of Environmental Justice which include; guaranteeing the right to environmental protection, preventing harm before it occurs, shifting the burden of Proof to the polluters, obviating proof of intent to discriminate and redressing existing inequalities.

All the people living in Portharcourt region have a right to be protected from negative effects of oil and gas Pipelines and the associated environmental degradation. Protecting this right will require not only the enacting a Federal Environmental Protection act but also the enforcement of such act. The act ought to address both the intended and unintended effects of Public Policies and Oil Companies' practices that have a disparate impact on local residents of Portharcourt region.

Prevention, elimination of the threat before harm occurs, should be the preferred strategy of the government of Portharcourt. For instance, to solve the Oil and Gas Pipelines spillages problems, the primary focus should be shifted from pollution cleaning as well as treating of water and people who have been poisoned to eliminating the threat by ensuring that oil and gas pipelines are properly buried beneath the earth surface, located far from human settlements as much as possible and proper and routing maintenance

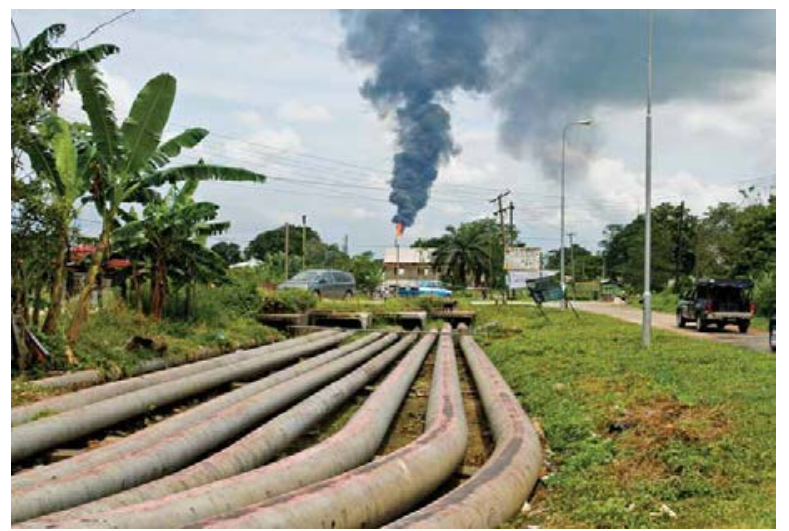

Fig. 2 Pipelines in neighbouring Okirika LGA, Rivers State

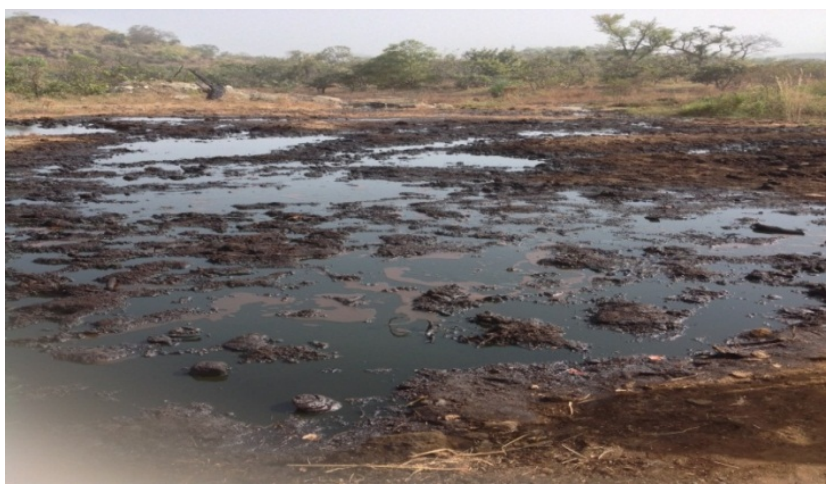

Fig.4 Vegetation land impacted by crude oil at Ogoni land 


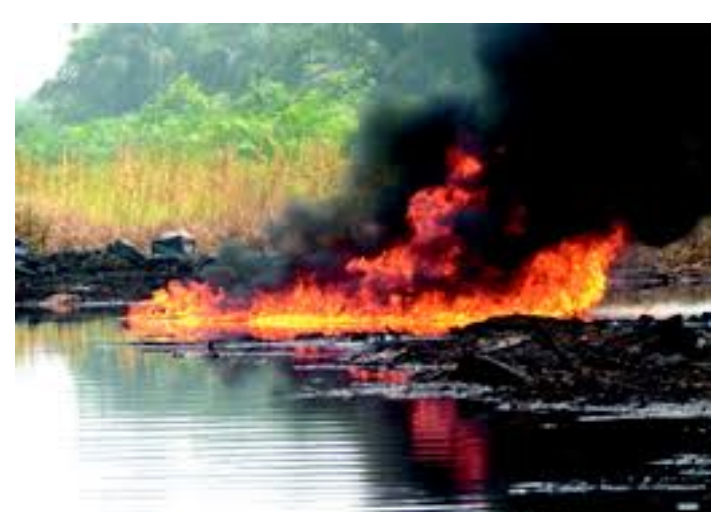

Fig. 5 Site engulfed with fire as a result of oil spill

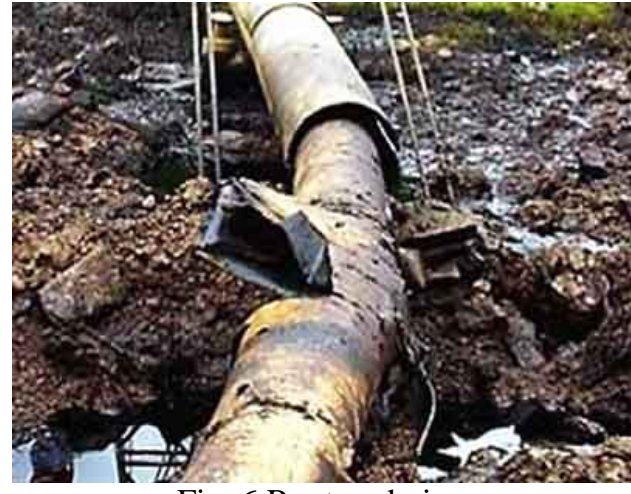

Fig. 6 Ruptured pipe

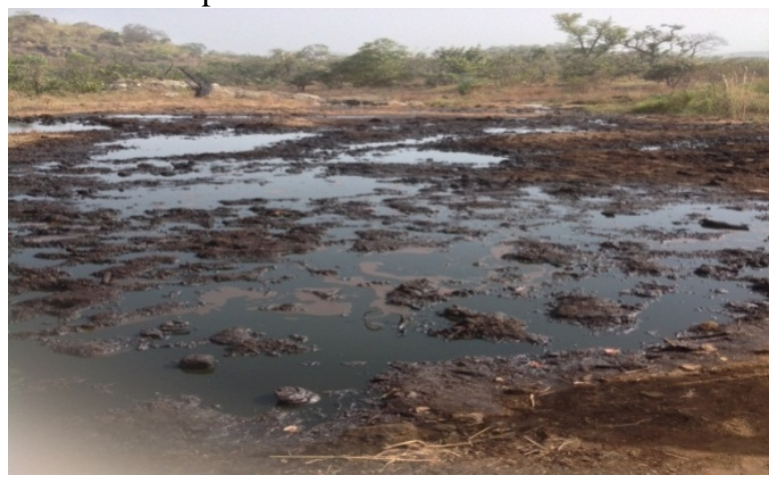

Fig. 7 Oil spill through broken pipe

TABLE I

SOCIO-ECONOMIC CHARACTERISTICS OF INDIVIDUALS WITHIN THE HOST COMMUNITIES OF PIPELINE VANDALISMS IN PORTHARCOURT,

\begin{tabular}{ll}
\multicolumn{2}{c}{ RIVERS STATE } \\
\hline \hline Variables & Number/(\%) \\
\hline Sex & \\
Males & 70 \\
Females & 30 \\
Total no. of respondents & 100 \\
Age (years) & \\
$20-25$ & 20 \\
$26-35$ & 35 \\
$36-45$ & 30 \\
46 and above & 15 \\
Total no. of respondents & 100 \\
Marital status & \\
Singles & 55 \\
Married & 40 \\
Widows & 05 \\
Total no. of respondents & 100 \\
Educational Status & \\
Primary School & 05 \\
Secondary school & 25 \\
Post- secondary school & 30 \\
Graduates & 40 \\
Total no. of respondents & 100 \\
Workers & \\
Top management Staff & 05 \\
Senior middle management staff & 25 \\
Company supervisors & 30 \\
Junior staff & 45 \\
Total no. of respondents & 100 \\
Workers Experience (Years) & \\
1-10 & 40 \\
11-20 21 and above & 50 \\
Total no. of respondents & 10 \\
& 100 \\
\hline \hline
\end{tabular}

TABLE II

ACHIEVEMENT AND NON -ACHIEVEMENT OF THE OIL COMPANIES TOWARD THEIR HOST COMMUNITIES ON PIPELINE VANDALISM

\begin{tabular}{llllll}
\hline \hline & $\begin{array}{l}\text { No. of } \\
\text { respondents }\end{array}$ & $\begin{array}{l}\text { Strongly } \\
\text { Agreed } \%\end{array}$ & Agreed \% & Disagreed \% & $\begin{array}{l}\text { Strongly } \\
\text { disagread\% }\end{array}$ \\
\hline 1. & 100 & 65 & 33 & 00 & 00 \\
2. & 100 & 25 & 10 & 40 & 25 \\
3. & 100 & 20 & 30 & 35 & 15 \\
4. & 100 & 10 & 15 & 40 & 35 \\
5. & 100 & 40 & 35 & 20 & 05 \\
6. & 100 & 55 & 42 & 02 & 01 \\
7. & 100 & 65 & 35 & 00 & 00 \\
8. & 100 & 40 & 35 & 15 & 10 \\
9. & 100 & 20 & 25 & 25 & 30 \\
10. & 100 & 25 & 50 & 20 & 05 \\
11. & 100 & 50 & 50 & 00 & 00 \\
12. & 100 & 50 & 45 & 05 & 00 \\
13. & 100 & 45 & 50 & 04 & 01 \\
\hline \hline
\end{tabular}

1. Pipeline vandalism in the host communities in Rivers State is very high.

2. The indigenes of the host communities in oil producing areas in Rivers State are usually placed in top positions in the oil companies.

3. The oil companies have been assisting their host communities by providing Educational facilities.

4. The oil companies in Rivers state have been complementing Government efforts in the provision of social amenities in their communities.

5. The oil companies in Rivers State have done very well in curbing and controlling the environmental degradation facing the host communities. 
6. The oil spillage due to pipeline vandalism has done a lot of damages to the Biodiversity in the areas of vandalism.

7. Many lives are lost due to explosions from the pipeline vandalism activities in the areas of vandalism within the host communities.

8. The oil companies usually provide health care facilities to the host communities within the areas of the pipeline vandalisms.

9. The oil companies in Rivers State do make some consultations with the host community members before embarking on some projects in the interest of the host community members.

10. The Government now has extensive programmes for the community development within the host communities in Rivers State.

11. The oil spillages due to pipeline vandalisms do have serious side effects on the flora and fauna within the regions in the host communities.

12. Oil spillage due to pipeline vandalisms usually causes serious damages to the land for Agricultural and fish farming activities in the host communities of Rivers State.

13. The oil spillages due to pipeline vandalisms do have a negative implication to the residents within the host communities and their environs.

\section{ACKNOWLEDGMENT}

The authors wish to thank National Population Commission [NPC] Rivers State Office, Portharcourt, staff of Rivers State Environmental Protection Agency and Nigerian National Petroleum Cooperation [NNPC], Portharcourt, Rivers State for their support.

\section{REFERENCES}

[1] R. K. Udo, Geographical Region of Nigeria. University of Califonia Press. 1970, p. 85.

[2] M. A. Onwuejeogwu, Nri Kingdom and Hegemony, Ethnographica, 1981.

[3] A. Babatunde, "The impact of oil exploitation on the socio-economic life of the Ilaje-Ugbo people of Ondo State, Nigeria”, Journal of Sustainable Development in Africa, vol. 12, no.5, 2010.

[4] A. Okoli, I. Chukwuma and O. Sunday, "Oil pipeline vandalism and Nigeria's national security”. Global Journal of Human Social Science Research, vol. 13, no.5, 2013.

[5] E. L. Vivan, "Socio-Economic Impact of the Oil Industry in the NigerDelta Region in Five Decades of Oil Production in Nigeria: Impact on Niger- Delta" in CENDS, Centre of Environmental and Niger- Delta Studies. Delta State University, Abraka, pp. 193-203, 2012.

[6] NNPC "Report of special committee on the review of petroleum product supply and distribution”, Nigerian National Petroleum Cooperation, 2015.

[7] NEITI "Annual report of the Nigerian extractive industry transparency initiative, NEITI, Nigeria, 2013.

[8] F. C. Onuoha, "Why the poor pay with their lives: oil pipeline vandalisation, fires and human security in Nigeria”, Disasters, vol. 33, no.3, pp.369-389, 2008. http://dx.doi.org/10.1111/j.1467-7717.2008.01079.x

[9] A. Brume. "Pipeline Vandalization in Niger Delta" presented at the $30^{\text {th }}$ Annual Conference of the Nigeria Geographical Association, held at FUT, Minna, 30 ${ }^{\text {th }}$ July - August, 2006.

[10] O. E. Adeniyi, "Environmental and Social Economic Impact of Oil Spillages in the Petroleum Producing Riverine Area of Nigeria", Proceeding of NNPC International Seminar on the Petroleum Industry and Nigerian Environment, 1998. 